\title{
ENTREPRENEURSHIP PEDAGOGIC STRUCTURE IMPACT ON THE ENTREPRENEURIAL MINDSET AND ENTREPRENEURSHIP KNOWLEDGE OF STUDENTS IN MALAYSIA
}

\author{
Chidimma Okeke a, David Yong b \\ ab Multimedia University, Cyberjaya, Malaysia \\ Corresponding email: chidiodira@gmail.com
}

\begin{abstract}
This study assesses and explicates the conceptualization of entrepreneurship education assessment in Malaysia by evaluating the role of entrepreneurship pedagogic structures in the post academic entrepreneurship investment outcomes of students. The proposed model evaluates the impact of an entrepreneurship pedagogic structure (i.e., curriculum content knowledge, content delivery, and forms of entrepreneurship education pedagogy) as the foundation toward the entrepreneurial mindset and the ability to develop the entrepreneurship knowledge competency of students. The findings from the partial least squares structural equation modeling, were conducted through a cross-sectional survey of 378 students who attended an academic entrepreneurship course in Malaysian universities, empirically validate the model. This model further explains the role of teachers in transmitting knowledge, thereby demonstrating their impact on the learning capacity, assimilation, and long-term anticipated entrepreneurial human capital assets of students.
\end{abstract}

Keywords: Curriculum Content Knowledge, Content Delivery, Entrepreneurship Pedagogic, Entrepreneurial Mindset, Entrepreneurship Knowledge.

\section{Introduction and Purpose}

Evidence-based assessment of the impact of entrepreneurial pedagogy is the foundation to the rethinking and re-conceptualization of academic entrepreneurship education. Consequently, an empirical study illuminating the impact of entrepreneurial pedagogy provides a systematic assurance of the educational standards in the field of entrepreneurship. Although research on the impact assessment of entrepreneurship education has been rather scarce (Okeke and Yong, 2016), entrepreneurship education assessment is a process that guides the determination of graduate employability, predicts student innovative performance, and helps educators evaluate their teaching philosophy (Duval-Couetil, 2013). Considering that entrepreneurship education is linked to innovation enablers who contribute to human capital development (Moberg et al., 2014), research into this field would help measure the objectives of the major forms of entrepreneurship education in real terms (Pittaway \& Edwards, 2012) and the anticipated aim of learning when compared with the innovative intuition of students (Fayolle \& Toutain, 2013; Middleton and Donnellon, 2014). This study aims to empirically assess the impact of entrepreneurial pedagogy on the anticipated outcome of entrepreneurship education from the prisms of the knowledge of students.

\section{Theory and Hypothesis Development}

This study considers the impact of entrepreneurship pedagogic structure on the mindset and entrepreneurship knowledge of individual students and the manner in which the explicit knowledge of educators on theories, concepts, ideas and teaching approaches reflects the cognitive development of individual students. The pedagogic structure should be 
demonstrated through the seamless and effectual transmittance of transformative pedagogy of educators to be visible and reflect on the innovative performance of students and to attain the anticipated learning outcomes. Consistent with the impact of entrepreneurship education (Fayolle and Gailly, 2015), the impact of entrepreneurship pedagogic structure is identified as a significant study that helps evaluate the design and implementation of academic entrepreneurship. Such a pedagogic structure refers to the soft skills that measure the real cognitive constructs of human capital development (Pittaway and Edwards, 2012; Duval-Couetil, 2013).

We define entrepreneurship pedagogic structure as the learning process that inculcates the systematic instruction of academic entrepreneurship to create the knowledge necessary to attain an entrepreneurial mindset, as well as obtain the skills and knowledge for stimulating innovative performance (Mwasalwiba, 2010; Okeke and Yong, 2016). The ensuing measures are (i) curriculum content knowledge $(\mathrm{CCnK})$, which is the foundation of knowledge and teaching; (ii) curriculum content delivery (CCD), which is the effective planning of instructional material and learning environment management; and (iii) forms of entrepreneurship education pedagogy (FEEP), which embody the philosophy that broadens innate capacity and stimulate value creation. The other two measures are (iv) the ability of students to develop entrepreneurial mindset and (v) the capacity to acquire entrepreneurship knowledge, which are mechanisms adopted to evaluate the anticipated outcomes of the impact of entrepreneurship pedagogic structure. The relevant hypotheses are presented as follows.

Curriculum content knowledge: Ball et al. (2008) described content knowledge as the domain knowledge, skills, and habits of the mind needed to teach and is employed in practice by educators. Cochran, King, and Deruiter (1991) asserted content knowledge as the base of knowledge that demonstrates the subject-matter know-how of individual teachers and thereby reflects the competence of teachers and is seen in the application of teaching. Bausmith and Barry (2011) investigated the importance of pedagogical content knowledge and empirically agreed that content knowledge enhances teaching and learning, and influences the right outcomes of the investment in education. Similarly, Gibb (2011) stated that content knowledge structure, as a concept to delivering effective entrepreneurship education, helps educators redefine the conceptual barriers of students, build frontiers of knowledge exploits and develop entrepreneurial competence. The content knowledge of entrepreneurship educators is immensely important in developing the entrepreneurial mindset and entrepreneurship knowledge of students and in measuring if its impact can help explicate the best method to transmit knowledge to students (Okeke and Yong, 2016). Thus, the following hypotheses are established:

H1a: The CCnK of teachers positively influences the ability of individual students to develop entrepreneurial mindset.

H1b: The CCnK of teachers positively influences the capacity of individual students to acquire entrepreneurial knowledge.

Curriculum content delivery: The fundamental concept of entrepreneurial pedagogy is premised on content delivery mechanisms and the manner in which it effectively transmits the three major aims of entrepreneurship education as follows: (i) to define the abstract constructs for understanding the cognitive disposition of students, (ii) to ensure that the reason to teach creates the value needed, and (iii) to measure the stipulated learning outcomes that are achieved (Legendre, 1993). Content delivery demonstrates how educators engage to explain contexts, and how it is applied for the effective management both outside and inside the classroom. Moberg (2014) empirically asserted that content delivery significantly affects the knowledge, skill set, and mindset of students, which they need to realize the purpose of learning. An empirical study has indicated that the attainment of the anticipated learning outcome in entrepreneurship education is determined by effectual content delivery methods (Mwasalwiba, 2010). The content delivery methods of teachers represent a philosophy that motivates, inspires and educates the mind of students in order to 
develop their capacity, which is necessary to stimulate knowledge and value creation attitudes (Pittaway and Edwards, 2012). Therefore, the following hypotheses are given:

H2a: The content delivery of teachers positively influences the ability of individual students to develop entrepreneurial mindset.

H2b: The content delivery of teachers positively influences the capacity of individual students to acquire entrepreneurial knowledge.

Forms of entrepreneurship education pedagogic: This measure is a strong disposition toward competency development, skill and knowledge and a strategic thinking capacity (Mwasalwiba, 2010). The distinct FEEP employed by educators has a strong influence on the self-confidence of students to engage in specific tasks and in the application of the acquired knowledge (Fayolle and Gailly, 2015). Relating goal-setting theory to measure the impact of entrepreneurial pedagogy, the study of White, Hertz, and D'Souza (2011) significantly showed that entrepreneurial pedagogy boosts teaching, precipitates relevant content useful to unpack and represents and creates value within specified time. On this basis, the following hypotheses are suggested:

H3a: The FEEP of teachers positively influences the ability of individual students to develop an entrepreneurial mindset.

$\mathrm{H} 3 \mathrm{~b}$ : The FEEP of teachers positively influences the capacity of individual students to acquire entrepreneurial knowledge.

Individual entrepreneurial mindset and entrepreneurship knowledge: Entrepreneurship education increases the motivation to develop an entrepreneurial mindset. Solesvik, Westhead, Matlay, and Parsyak (2013) stated that entrepreneurial mindset increases the alertness and motivation of students with regard to entrepreneurial knowledge. Haynie, Shepherd, Morakowski, and Earley (2010) opined that entrepreneurial mindset offers a potential insight into different outcomes and situations fundamental to entrepreneurship research. Fayolle and Gailly (2015) asserted that entrepreneurship education impacts individual mindset, which ensures the capacity to acquire entrepreneurial knowledge that helps an individual to focus on a viable career path. The anticipated long-term investment outcome of entrepreneurial knowledge is the production of an entrepreneur that permeates the personal, social and professional lives of a person (Moberg et al., 2014). Haynie et al. (2010) empirically affirmed the strong link of entrepreneurial mindset to the effectual reasoning, entrepreneurial cognition and ability of an individual to acquire and leverage uncommon valuable resources. The following hypothesis is accordingly provided:

H4: The ability of an individual to develop an entrepreneurial mindset positively influences the capacity of this individual to acquire entrepreneurial knowledge.

\section{Methodology}

The data were collected between May and October of 2016 from students both in private and public universities in Malaysia, and the students who participated should have taken a full academic module of entrepreneurship subject. The entrepreneurship program for higher education development policy of the Ministry of Education is to promote, produce, strengthen and nurture holistic academic entrepreneurship. This was consulted to understand the anticipated aims of entrepreneurship programs in Malaysian universities and to ensure that the impact was exhaustively measured (Yusoff, Zainol, and Ibrahim, 2014). Therefore, universities that have developed an internal entrepreneurship and innovation program as a core policy that governs the university academic engagement were selected as the lowest unit of engagement. The consent of the university faculties was obtained, and the students who participated in the survey were briefed adequately. Explanations were offered to explicate the objective of the study to help students overcome pressure and to make them feel comfortable in responding to the questions without bias. To attain the objective of this study and reduce sampling error, the stratified random sampling technique was used to select the universities from where the expected sample respondents were chosen through unrestricted random sampling. Probability sampling techniques are primarily suited for 
quantitative studies that aim to achieve representatives that would accurately represent the research intention with the least bias of generalizability (Teddlie and Yu, 2007; Sekaran and Bougie, 2013). The final analysis was conducted with 378 questionnaires, which represented $75.6 \%$ of the total 500 questionnaires.

The constructs were measured with scales adopted from the literature, and the assessment scales were based on a five-point Likert scale (ranging from $1=$ strongly disagree to $5=$ strongly agree). The preliminary question was put through an academic expert evaluation and a pretest pilot study with 38 respondents. From their suggestions and comments, the necessary corrections were implemented as the questions were rephrased to enhance clarity. The CCnK impact was measured with 6 items $(\alpha=0.829)$, the CCD impact was measured with 6 items $(\alpha=0.86)$, and the FEEP $(\alpha=0.918)$ impact was measured with 13 items. The ability to develop an entrepreneurial mindset $(\alpha=0.83)$ was measured with six items, and the capacity to acquire entrepreneurial knowledge $(\alpha=0.784)$ was measured with three items. Table 2 reports the measurement model specification by presenting the construct outer loadings, composite reliability (CR), Cronbach's alpha, average variance extracted (AVE), and discriminant validity [heterotrait-monotrait ratio of correlations (HTMT)].

Table 1: Hypothesis testing of the structural model

\begin{tabular}{|c|c|c|c|c|c|c|c|}
\hline $\begin{array}{l}\text { Hypot } \\
\text { hesis }\end{array}$ & Relationship & $\begin{array}{l}\text { Std. } \\
\text { beta }\end{array}$ & $\begin{array}{l}\text { Std. } \\
\text { error }\end{array}$ & t-value & $\begin{array}{c}\text { p-val } \\
\text { ue }\end{array}$ & $\begin{array}{c}\text { Confidence } \\
\text { interval }\end{array}$ & Decision \\
\hline H1a & $\begin{array}{l}\text { CCnK -> } \\
\text { Mindset }\end{array}$ & 0.142 & 0.066 & 2.147 & $0.016^{*}$ & $0.038,0.252$ & Supported \\
\hline $\mathrm{H} 1 \mathrm{~b}$ & CCnK -> EKNC & 0.205 & 0.074 & 2.788 & $\underset{*}{0.003^{*}}$ & $0.070,0.322$ & Supported \\
\hline $\mathrm{H} 2 \mathrm{a}$ & $\begin{array}{l}\text { CCD -> } \\
\text { Mindset }\end{array}$ & 0.141 & 0.071 & 1.972 & $0.025^{*}$ & $0.035,0.270$ & Supported \\
\hline $\mathrm{H} 2 \mathrm{~b}$ & CCD -> EKNC & 0.038 & 0.078 & 0.484 & 0.314 & “-0.097, $0.154 "$ & $\begin{array}{c}\text { Not } \\
\text { Supported }\end{array}$ \\
\hline $\mathrm{H}_{3} \mathrm{a}$ & $\begin{array}{l}\text { FEEP -> } \\
\text { Mindset }\end{array}$ & 0.467 & 0.052 & 8.947 & $\underset{* *}{0.000}$ & $0.372,0.543$ & Supported \\
\hline $\mathrm{H}_{3} \mathrm{~b}$ & FEEP -> EKNC & 0.114 & 0.077 & 1.483 & 0.069 & $\begin{array}{c}\text { “-0.004, } \\
0.252 "\end{array}$ & $\begin{array}{c}\text { Not } \\
\text { Supported }\end{array}$ \\
\hline $\mathrm{H}_{4}$ & $\begin{array}{c}\text { Mindset -> } \\
\text { EKNC }\end{array}$ & 0.304 & 0.067 & 4.553 & $\underset{* *}{0.000}$ & $0.192,0.414$ & Supported \\
\hline
\end{tabular}

Table 2: Measurement model specification with partial least squares structural equation modeling

\begin{tabular}{|c|c|c|c|c|c|c|c|}
\hline Model construct & $\begin{array}{c}\text { Measuremen } \\
\text { t item }\end{array}$ & $\begin{array}{c}\text { Loading } \\
\mathrm{s}>0.6\end{array}$ & $\begin{array}{c}\text { CR } \\
\text { o.6-0. } \\
9\end{array}$ & $\begin{array}{c}\text { AVE } \\
>0.5\end{array}$ & $\begin{array}{c}\text { Varianc } \\
\text { e } \\
\text { inflatio } \\
\text { n factor }\end{array}$ & $\begin{array}{c}\text { Cronbac } \\
\text { h's alpha }\end{array}$ & $\begin{array}{c}\text { HTMT } \\
\text { confidence } \\
\text { interval } \\
\text { does not } \\
\text { include 1 }\end{array}$ \\
\hline $\mathrm{CCD}$ & $\mathrm{CCD} 1$ & 0.752 & 0.896 & 0.59 & 2.326 & 0.86 & Yes \\
\hline & $\mathrm{CCD} 2$ & 0.827 & & & 2.896 & & \\
\hline & $\mathrm{CCD} 3$ & 0.793 & & & 1.943 & & \\
\hline & $\mathrm{CCD} 4$ & 0.777 & & & 1.894 & & \\
\hline & $\mathrm{CCD} 5$ & 0.708 & & & 1.577 & & \\
\hline & $\mathrm{CCD} 6$ & 0.748 & & & 1.736 & & \\
\hline & $\mathrm{CCnK} 1$ & 0.716 & 0.874 & 0.53 & 1.5 & 0.829 & Yes \\
\hline & $\mathrm{CCnK} 2$ & 0.713 & & & 1.515 & & \\
\hline & $\mathrm{CCnK} 3$ & 0.757 & & & 2.33 & & \\
\hline
\end{tabular}




\begin{tabular}{|c|c|c|c|c|c|c|c|}
\hline & $\mathrm{CCnK} 4$ & 0.77 & & & 2.397 & & \\
\hline & $\mathrm{CCnK}_{5}$ & 0.728 & & & 1.749 & & \\
\hline & CCnK6 & 0.711 & & & 1.653 & & \\
\hline \multirow[t]{3}{*}{$\begin{array}{c}\text { Entrepreneurial } \\
\text { knowledge }\end{array}$} & EKNC1 & 0.862 & 0.874 & $\begin{array}{c}0.69 \\
8\end{array}$ & 1.693 & 0.784 & Yes \\
\hline & EKNC2 & 0.849 & & & 1.734 & & \\
\hline & EKNC3 & 0.793 & & & 1.524 & & \\
\hline \multirow[t]{13}{*}{ FEEP } & FEEP3 & 0.672 & 0.93 & $\begin{array}{c}0.50 \\
5\end{array}$ & 1.765 & 0.918 & Yes \\
\hline & FEEP6 & 0.676 & & & 1.876 & & \\
\hline & FEEP7 & 0.66 & & & 1.658 & & \\
\hline & FEEP10 & 0.663 & & & 1.756 & & \\
\hline & FEEP11 & 0.711 & & & 1.876 & & \\
\hline & FEEP12 & 0.744 & & & 1.969 & & \\
\hline & FEEP13 & 0.717 & & & 2.095 & & \\
\hline & FEEP14 & 0.738 & & & 2.021 & & \\
\hline & FEEP15 & 0.696 & & & 1.767 & & \\
\hline & FEEP16 & 0.758 & & & 2.032 & & \\
\hline & FEEP17 & 0.759 & & & 2.234 & & \\
\hline & FEEP18 & 0.701 & & & 1.815 & & \\
\hline & FEEP19 & 0.736 & & & 1.976 & & \\
\hline \multirow[t]{6}{*}{$\begin{array}{l}\text { Entrepreneurial } \\
\text { mindset }\end{array}$} & MINDSET1 & 0.729 & 0.876 & $\begin{array}{c}0.54 \\
1\end{array}$ & 1.601 & 0.83 & Yes \\
\hline & MINDSET2 & 0.767 & & & 1.785 & & \\
\hline & MINDSET3 & 0.714 & 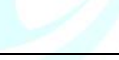 & 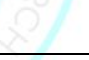 & 1.538 & & \\
\hline & MINDSET4 & 0.706 & & 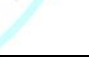 & 1.539 & & \\
\hline & $\mathrm{MINDSET}_{5}$ & 0.711 & +2 & & 1.725 & & \\
\hline & MINDSET6 & 0.781 & & & 1.912 & & \\
\hline
\end{tabular}

\section{Analyses and Results}

The structural model path coefficients were utilized to obtain the estimates that represent the hypothesized relationship among the constructs. The tolerance (variance inflation factor) value of each of the predictor construct (see Table 2) was lower than the threshold of 5, which confirmed that the independent variables did not contain any critical levels of collinearity (Hair et al., 2017). Bootstrapping was performed to assess the significance of the path coefficients. Hair et al. (2014) posited that a look at the beta and t-values through the bootstrapping process with a resample of 5,000 confirmed the significance of the path coefficients.

We explored the predictors of the capacities of students to develop an entrepreneurial mindset and to acquire entrepreneurial knowledge, which were the CCnK, CCD, and FEEP. A significant path was obtained from the impact of CCnK on the ability of students to develop an entrepreneurial mindset $(\beta=.142, \mathrm{p}<.05)$ and on the capacity of students to acquire entrepreneurial knowledge $(\beta=.205, \mathrm{p}<.01)$. The impact of CCD on the ability of students to develop an entrepreneurial mindset was significant $(\beta=.141, p<.05)$, whereas the impact on N the capacity of students to acquire entrepreneurial knowledge was insignificant. Thus, H1a, $m$ H1b, and H2a were supported, whereas H2b was unsupported. The FEEP impact on the ability to develop entrepreneurial mindset was significant $(\beta=.467, \mathrm{p}<.01)$, whereas the 
impact on the capacity to acquire entrepreneurial knowledge was insignificant $(\beta=.114, p<$ $\mathrm{ns}$ ); therefore, H3b was unsupported. Finally, the ability of students to develop an entrepreneurial mindset influenced their capacity to acquire entrepreneurial knowledge $(\beta=.304, \mathrm{p}<.01)$. Thus, $\mathrm{H} 4$ was supported. The structural path model analysis is presented in Figure 1.

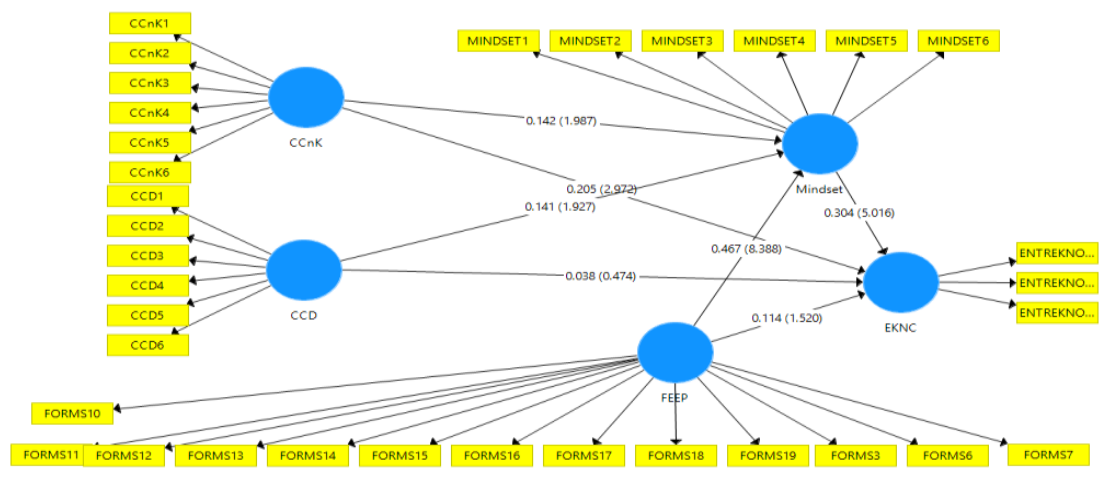

Figure 1: Structural Model Analysis

\section{Discussion}

Revisiting the entrepreneurship education program assessment model by Fayolle et al. (2006), this study draws the impact of entrepreneurship pedagogic structure to specifically assess the teaching mechanisms of entrepreneurship module from the perspective of students from Malaysian universities. The hypotheses show that the CCnK, CCD, and FEEP of teachers significantly influence the ability of students to develop an entrepreneurial mindset. The lack of direct impact between $\mathrm{CCnK}$ and FEEP on the capacity of students to acquire entrepreneurial knowledge could be attributed to the empirical links among entrepreneurship education, motivation of students to gain an entrepreneurial mindset, and entrepreneurship education investment outcomes (Solesvik et al., 2013).

Fayolle and Toutain (2013) posited that the teaching model demonstrated in the entrepreneurial pedagogy through the notion to educate for entrepreneurship achieves the learning processes and methods that develop concrete knowledge of know-what, know-how, and know-who long-term objectives of entrepreneurship education. Thus, the impact assessment contributes to the understanding of the current task and rethinking of teaching entrepreneurship. The findings explicate what entrepreneurship educators need to focus on and to gauge the knowledge, skills, and senses necessary in the design and development for transmitting the right pedagogy. Accordingly, this study should motivate educators to reconceptualize and rethink the content, context, forms and instructional purpose to measure the essence of teaching and the apparent knowledge required to attain post-entrepreneurship education objective. Succinctly, teaching involves strategies to relate content and apply such strategies to the target audience with the intent to create knowledge, value and a community of innovative creators (Ball et al., 2008).

\section{Conclusion and Future Work}

Consistent with recent concepts for the need for impact assessment of academic entrepreneurship education (Fayolle and Gailly, 2008; Pittaway and Edwards, 2012; Duval-Couetil, 2013; Moberg, 2014), the present findings demonstrate the specifics of entrepreneurship pedagogic structure that ensures capacity building of the competency and knowledge of students. Nevertheless, clarity should be enhanced to ascertain the specific pedagogy that can profile and identify students. This formative process could be a catalyst to develop the right competency and incremental mindset that would bridge the gap between graduate employability and entrepreneurial innovation. The attendant weakness of CCnK and CCD could be checked by educators by rethinking the design of pedagogy that would play an important role in the formative process and reposition the experience of students outside the classroom. Future research should consider the impact of evidence-based entrepreneurial pedagogy to simultaneously measure the capacity of students to exploit and discover their 
entrepreneurial identity. Finally, the validated model should be expanded to the contexts of other institutions (e.g., vocational and high schools) in order to measure and to establish the general concepts of the findings. 


\section{References}

i. Ball, D. et al., 2008. Content Knowledge for Teaching: What Makes It Special?. Journal of Teacher Education, 59(5), pp. 389-407.

ii. Bausmith, J. \& Barry, C., 2011. Revisiting professional learning communities to increase college readiness: The importance of pedagogical content knowledge. Educational Researcher, 40(4), pp. $175-178$.

iii. Cochran, K., King, R. \& DeRuiter, J., 1991. Pedagogical content knowledge: A tentative model for teacher preparation. Paper presented at the Annual Meeting of the American Educational Research Association., s.l.: American Educational Research Association..

iv. Duval-Couetil, N., 2013. Assessing the impact of Entrepreneurship education programs: challenges and approaches. Journal of Small Business Management, 51(3), pp. 395-409.

v. Fayolle, A. \& Gailly, B., 2008. From craft to science: Teaching models and learning processes in entrepreneurship education. Journal of European Industrial Training, 32(7), pp. 569-593.

vi. Fayolle, A. \& Gailly, B., 2015. The impact of entrepreneurship education on entrepreneurial attitudes and intention: Hysteresis and persistence.. Journal of Small Business Management, 53(1), pp. 75-93.

vii. Fayolle, A., Gailly, B. \& Lassas-Clerc, N., 2006. Assessing the impact of entrepreneurship education programmes: A new methodology. Journal of European Industrial Training, 30(9), pp. 701-720.

viii. Fayolle, A. \& Toutain, O., 2013. Four educational principles to rethink entrepreneurship education. Revista De Economia Mundial, Volume 35, pp. 165-176.

ix. Gibb, A., 2011. Concepts into practice: meeting the challenge of development of entrepreneurship educators around an innovative paradigm. International Journal of Entrepreneurial Behaviour \& Research, 17(2), pp. 146-165.

x. $\quad$ Hair, J., Hult, G., Ringle, C. \& Sarstedt, M., 2004. A Primer on Partial Least Squares Structural Equation Modeling (PLS-SEM). 2nd ed. Thousand Oaks: Sage Publications.

xi. $\quad$ Hair, J., Hult, G., Ringle, C. \& Sarstedt, M., 2017. A Primer on Partial Least Squares Structural Equation Modeling (PLS-SEM). 2nd ed. Thousand Oaks, CA: Sage Publications.

xii. Haynie, J., Shepherd, D., Mosakowski, E. \& Earley, P., 2010. A situated metacognitive model of entrepreneurial mindset. Journal of Business Venturing, 25(2), pp. 17-29.

xiii. $\quad$ Legendre, R., 1993. Dictionnaire actuel de l'education. 2nd ed. s.l.:Larousse.

xiv. Middleton, K. \& Donnellon, A., 2014. Personalizing Entrepreneurial Learning: A Pedagogy for Facilitating the Know Why. Entrepreneurship Research Journal, 4(2), pp. 167-204.

xv. Moberg, K., 2014. Assessing the Impact of Entrepreneurship Education. From ABC to PHD, Copanhagen: Department of strategic Management, Copanhagen Business School.

xvi. Moberg, K. et al., 2014. How to assess and evaluate the influence of entrepreneurship education.. s.l.:s.n.

xvii. Mwasalwiba, S., 2010. Entrepreneurship education: a review of its objectives, teaching methods, and impact indicators.. Education and Training, 52(1), pp. 20-47.

xviii. Okeke, C. \& Yong, D., 2016. Assessment of entrepreneurship pedagogy on entrepreneurship knowledge and entrepreneurial human capital asset: A Conceptual model. Knowledge Management and E-Learning, 8(2), pp. 243-248.

xix. Pittaway, L. \& Edwards, C., 2012. Assessment: Examining practice in enterprise education. Education + Training, Volume 54, pp. 778-800.

xx. $\quad$ Sekaran, U. \& Bougie, R., 2013. Research Methods for Business: A Skill-Building approach. 6th ed. New York: John Wiley \& Sons. 
xxi. $\quad$ Solesvik, Z., Westhead, P., Matlay, H. \& Parsyak, N., 2013. Entrepreneurial Assets and Mindsets : Benefit From University Entrepreneurship Education Investment.. Education + Training, 55(8/9), pp. 748-762.

xxii. Teddlie, C. \& Yu, F., 2007. Mixed Methods Sampling: A Typology With Examples. Journal of Mixed Methods Research, 1(1), pp. 77-100.

xxiii. Yusoff, et al., 2014. Entrepreneurship Education in Malaysia's Public Institutions of Higher Learning-A Review of the Current practises. International Education Studies, 8(1), pp. 17-28. 